\title{
Considerações a respeito de avaliações
}

$\mathrm{T}$ odos concordam com a necessidade de existirem avaliações de desempenho, seja de docentes e alunos, seja de departamentos, disciplinas e cursos.

Por que, então, os últimos processos avaliativos, que envolveram docentes da Faculdade de M edicina de Ribeirão Preto, geraram tanto descontentamento?

Para avaliar adequadamente é necessário, entre outros itens, explicitar os objetivos, fornecer elementos para que os avaliados possam atingi-los, utilizar um instrumento adequado e usar critérios bem estabelecidos e divulgados, que permitam uniformidade nos conceitos emitidos pelos avaliadores (sempre que possível, deve ser feito o "pareamento" dos avaliadores).

A reflexão a respeito de três dos processos de avaliação mais criticados, nos últimos dois anos a avaliação da CA PES, de 1998; a avaliação da Comissão de Pós-Graduação, realizada na ocasião do recredenciamento de orientadores, e a avaliação da CERT, de 1999 - levou-me a fazer as considerações que se seguem.

A avaliação da CAPES tem objetivos e critérios claros e divulgados; cabe a cada curso encontrar meios de atingí-los; os avaliadores seguiram os critérios com uniformidade (posso afirmar que, na área de M edicina III, isso ocorreu); o coordenador e o vice-coordenador da área conferiram os resultados, para garantir a homogeneidade; mas, infelizmente, 0 instrumento utilizado originou algumas confusões - o formulário é extenso, algumas perguntas geram dúvidas, e informações importantes foram perdidas, por terem sido omitidas ou inadequadamente explicitadas. Julgo que isso tenha motivado o desagrado de alguns cursos. Para corrigir isso, a CAPES planejou uma reunião, que tem, como um dos temas, a orientação para 0 preenchimento de formulários.

$\mathrm{Na}$ avaliação da Comissão de Pós-Graduação 0 instrumento utilizado era adequado, os ob- jetivos e critérios foram claros e amplamente divulgados, e os avaliadores atuaram com uniformidade. Na minha opinião, o problema foi que as chances de cumprir os critérios não foram uniformemente distribuídas. $\mathrm{N}$ as áreas com maior demanda (relativamente ao número de orientadores), era mais fácil ser aprovado, enquanto que, em outras, para alguns docentes era inviável cumprir os requisitos, pois não tinham acesso a orientandos.

É amplamente divulgado que a avaliação da CERT tem como objetivo premiar a "excelência". Os docentes sabem que 0 instrumento utilizado é o relatório, elaborado por eles mesmos, e conhecem o que é entendido como "excelência". Nem todos têm idênticas condições externas para atingí-la, mas não foi isso que gerou o desagrado. Na minha percepção, ele foi gerado pela não divulgação de critérios objetivos e pela notória falta de uniformidade das avaliações individuais. Existem várias suposições sobre eventuais critérios, e um dos mais apontados como muito valorizado é a publicação de trabalhos completos em periódicos indexados. A pesar de os resultados terem sido sigilosos, muitos docentes tornaram públicas as avaliações que receberam. Fazendo-se um exercício com os vários critérios aventados, fica claro que iguais não foram igualmente aquinhoados e que algumas desigualdades foram consideradas. Dá para entender porque muitos se sentiram injustiçados.

Seria conveniente que a Faculdade de $\mathrm{Me}$ dicina de Ribeirão Preto promovesse um "forum" de debates, com a participação de representantes das entidades promotoras das avaliações e do qual todos os docentes pudessem participar.

\author{
Profa.Dra. MARIA DE LOURDES V. RODRIGUES \\ Editora da Revista M edicina
}

